\title{
Nitrite is a cGMP generator in isolated platelets
}

\author{
Alessandra Borgognone ${ }^{1,2}$, Thomas Loka ${ }^{1}$, Myriam Chimen ${ }^{1}$, Ed Rainger ${ }^{1}$, Martin Feelisch ${ }^{3}$, Steve P Watson ${ }^{1}$, \\ Michael P Frenneaux ${ }^{2}$, Melanie Madhani ${ }^{1^{*}}$ \\ From 7th International Conference on cGMP Generators, Effectors and Therapeutic Implications \\ Trier, Germany. 19-21 June 2015
}

cGMP is generated in blood platelets following activation of soluble guanylate cyclase (sGC) by nitric oxide (NO). Once synthesised, cGMP activates cGMP-dependent protein kinase (PKG) and causes an increase in intracellular cAMP concentration by inhibiting phosphodiesterase 3 (PDE3), responsible for its degradation. PKG and the cAMP-dependent protein kinase (PKA) phosphorylate a number of substrates with inhibitory effects on platelet function [1]. While NO is mainly generated by endothelial NO synthase (eNOS) in the endothelium, reduction of nitrite constitutes an alternative vascular source of $\mathrm{NO}$ during hypoxic and acidic conditions. Nitrite originates from reduction of dietary nitrate, found in foods such as beetroot and green leafy vegetables. Nitrite in the circulation can be converted to NO by several nitrite reductases in blood and tissues [2], and triggers vasodilatation [3] thus lowering blood pressure [4]. It has also been demonstrated that when eNOS activity is impaired, NO generated through the nitrate/nitrite pathway exerts negative effects on platelet function [5].

Whilst deoxyhaemoglobin is a candidate nitrite-reductase in blood [6], we aimed to characterise the effects of nitrite in isolated platelets. As such, we used a preparation of washed platelets and supraphysiological concentrations of nitrite in vitro and characterised nitrite-dependent cGMP generation and inhibition of platelet function.

Our data show that nitrite at high concentrations $(1 \mathrm{mM})$ is a powerful generator of cGMP in platelets in the absence of extracellular reductases. While cGMP accumulation is inhibited by sGC inhibitor ODQ, NO scavengers have a partial effect. This seems to indicate that nitrite acts through both $\mathrm{NO}$-dependent and independent mechanisms. Accordingly, phosphorylation of the the cAMP and cGMP-dependent substrate VASP is strongly

\footnotetext{
* Correspondence: m.madhani@bham.ac.uk

${ }^{1}$ Centre for Cardiovascular Sciences, University of Birmingham, Birmingham, UK

Full list of author information is available at the end of the article
}

increased and, similarly to cGMP generation, is completely dependent on sGC activity but not NO. The increase of cGMP induced by high concentrations of nitrite inhibits platelet function as measured by platelet aggregation and secretion. However, whilst being dependent on sGC activity, the effect of nitrite on aggregation is not dependent on NO.generation. Lower concentrations of nitrite synergise with inhibition of PDEs, in particular PDE5 responsible for cGMP degradation, to trigger detectable VASP phosphorylation and inhibition of aggregation.

Nitrite triggers generation of cGMP in platelets and exerts inhibitory effects independently of extracellular reductases and other blood cells. Nitrite acts partly through reduction to $\mathrm{NO}$ and partly through an uncharacterised direct effect on sGC.

\section{Authors' details}

${ }^{1}$ Centre for Cardiovascular Sciences, University of Birmingham, Birmingham, UK. ${ }^{2}$ Norwich Medical School, University of East Anglia, Norwich, UK. ${ }^{3}$ Clinical and Experimental Sciences, Faculty of Medicine, University of Southampton, Southampton, UK.

Published: 2 September 2015

\section{References}

1. Smolenski A: Novel roles of CAMP/cGMP-dependent signaling in platelets. J Thromb Haemost 2012, 10(2):167-176.

2. Lundberg JO, Carlstrom M, Larsen FJ, Weitzberg E: Roles of dietary inorganic nitrate in cardiovascular health and disease. Cardiovasc Res 2011, 89(3):525-532.

3. Bailey JC, Feelisch M, Horowitz JD, Frenneaux MP, Madhani M: Pharmacology and therapeutic role of inorganic nitrite and nitrate in vasodilatation. Pharmacol Ther 2014, 144(3):303-320.

4. Kapil V, Milsom AB, Okorie M, Maleki-Toyserkani S, Akram F, Rehman F, et al: Inorganic nitrate supplementation lowers blood pressure in humans: role for nitrite-derived NO. Hypertension 2010, 56(2):274-281.

5. Apostoli GL, Solomon A, Smallwood MJ, Winyard PG, Emerson M: Role of inorganic nitrate and nitrite in driving nitric oxide-cGMP-mediated inhibition of platelet aggregation in vitro and in vivo. J Thromb Haemost 2014, 12(11):1880-1889.

6. Corti P, Tejero J, Gladwin MT: Evidence mounts that red cells and deoxyhemoglobin can reduce nitrite to bioactive NO to mediate intravascular endocrine NO signaling: commentary on "Anti-platelet 
effects of dietary nitrate in healthy volunteers: involvement of cGMP and influence of sex". Free Radic Biol Med 2013, 65:1518-1520.

doi:10.1186/2050-6511-16-S1-A65

Cite this article as: Borgognone et al: Nitrite is a cGMP generator in

isolated platelets. BMC Pharmacology and Toxicology 2015 16(Suppl 1):A65.

Submit your next manuscript to BioMed Central and take full advantage of:

- Convenient online submission

- Thorough peer review

- No space constraints or color figure charges

- Immediate publication on acceptance

- Inclusion in PubMed, CAS, Scopus and Google Scholar

- Research which is freely available for redistribution

Submit your manuscript at 